\title{
The Politics of Reorganizing Connecticut State Government: Altering Administrative Structures in the Land of Steady Habits
}

\author{
Lesley DeNardis, Ph.D (Corresponding author) \\ Department of Government and Politics \\ Sacred Heart University \\ Fairfield, Connecticut 06511 \\ Email: denardisl@sacredheart.edu
}

Received: July 20, 2011 Accepted: July 28, 2011 DOI: 10.5296/jpag.v1i1.816

\begin{abstract}
Despite numerous attempts to reorganize state government aimed at streamlining, reducing, and creating greater efficiencies, the size and scope of Connecticut's administrative apparatus has grown considerably over a fifty year period. This study will trace the political history of previous reorganization efforts with a particular emphasis on more recent attempts such as the Etherington (1970), Filer (1976), Gengras (1977), Thomas (1991), and Hull-Harper Commissions (1992). Observed trends follow national patterns: 1) reorganization commissions are cyclical in nature and more likely to be undertaken in the wake of similar efforts at the federal level and 2) they are more likely to be undertaken during periods of state fiscal retrenchment. A movement away from comprehensive reform efforts to incremental approaches is another cross-national pattern that has been detected in recent reform efforts. A review of Connecticut's experience with state reorganization demonstrates that despite the concerted effort by both the executive and legislative branches to alter administrative structures, reorganization recommendations are seldom implemented due to the opposition of the state legislature and interest groups.
\end{abstract}

Keywords: Administrative structures, Connecticut State, Reorganize, Politics 


\section{Introduction}

With severe fiscal crises affecting state governments across the United States, governors are increasingly turning to state reorganization as a tool to reign in government spending and close budget gaps for fiscal year 2011 (National Governors Association 2010). While Connecticut has experienced budget deficits periodically since the 1970s, the current budget deficit is the largest in state history. With an eye towards a more efficient and effective government, Connecticut governors since Wilbur Cross have utilized their powers to initiate state reorganization as a means to achieve greater control over the executive branch and in more recent years to reign in government spending. Yet despite numerous attempts to reorganize state government aimed at streamlining, reducing, and creating greater efficiencies, the size and scope of Connecticut's administrative apparatus has grown considerably over a fifty year period. This increase in the size and scope of government raises the question of how effective state reorganization efforts have been in the past and what the future prospects are for those who attempt the same.

This study will trace the political history of state reorganization with a particular emphasis on more recent attempts such as the Etherington (1970), Filer (1976), Gengras (1977), Thomas (1989-91), and Hull-Harper Commissions (1992). Administrative reorganization has been an abiding concern among state governments since the advent of the Progressive Era's quest to create a science of management. Connecticut's attempts at reorganization mirror national patterns in the following respects: 1) state reorganization is cyclical in nature and more likely to be undertaken in the wake of similar efforts at the federal level, 2) it is more likely to be undertaken during periods of state fiscal retrenchment and 3) since the 1990s, reorganization has retreated from comprehensive reform efforts in favor of more incremental and piecemeal approaches. In terms of prospects for the adoption and implementation of reorganization plans, a review of Connecticut's experience demonstrates that despite the concerted effort by governors to alter administrative structures and streamline government operations, reorganization recommendations are seldom implemented in their entirety due to the opposition of the state legislature and interest groups. Finally, the paper will offer some predictions with respect to Governor Malloy's most recent proposal to reorganize state government in light of lessons drawn from previous gubernatorial attempts at reorganization in Connecticut.

\section{The Rage to Reorganize}

The interest in government reorganization has been a century-old struggle that was born out of the scientific management movement at the turn of the twentieth century. As James Conant (1988) observed, the wellsprings of state reorganization was Woodrow Wilson's (1887) seminal work “The Study of Administration”. The first to suggest that there should be a separate discipline known as government administration distinct from politics, this politics/administration dichotomy led to other Progressive Era reformers to emphasize the now familiar and oft repeated mantras of effectiveness, efficiency, and economy as the

guiding principles of the new science of administration. Soon to follow were government attempts to implement these principles beginning with the Brownlow Committee Report of 
1937 which was inspired by Luther and Gulick's (1937) "Papers on the Science of Administration”. Chief executives, be they presidents or governors, have sought to achieve greater organizational control as they endeavored to "faithfully execute the laws." Staking their careers on their ability to effectively implement their policy agendas, chief executives have had to contend with unwieldy organizational structures that have grown in a haphazard or unplanned fashion, often by accretion over the course of time. The net result has impeded gubernatorial efforts to exert greater control over the executive branch. In Connecticut, various commissions have been convened at periodic intervals throughout the twentieth century, at the behest of governors, to study and make recommendations regarding administrative structures.

Collectively, these efforts have comprised part of a larger tradition in the United States known as the administrative reorganization movement. AE Buck's seminal work The Reorganization of State Governments in the United States (1938) took the general principles set forth by federal reformers and applied them to state government. The major principles or goals of state reorganization according to Buck are: 1) concentration of authority within the chief executive, 2) functional integration of independent agencies, 3) the avoidance of boards for purely administrative work, 4) coordination of staff services, 5) independent audits, and 6) recognition of a governor's cabinet. Taken together these principles also comprise what Bell (1974) termed "the cabinet" model of government which sought to give the governor greater control over the executive branch through fewer agencies, a high degree of functional consolidation, and the ability of the governor to appoint department heads.

With respect to the first of Buck's principles, the call for greater executive control was in reaction to the deliberate creation of weak state governors by colonial legislatures. Owing to the British colonial experience, the framers of state constitution were reluctant to vest too much power in the chief executive. In fact, as Devine (2006) observed: "During the Revolutionary period, many considered governors tyrants for enforcing what were perceived to be the abusive policies of King George III. From this came the stigmatization of gubernatorial power that discouraged a strong governorship through early U.S. history.” (p. 29)

Since many states were still living under constitutions that were designed during colonial times, conventions were called during the 1960's prompted primarily by the need to comply with the U.S. Supreme Court decision of Reyonolds v. Sims (1964) that called for "one man, one vote". While at the conventions, delegates addressed other outstanding issues in order to modernize their state governments. In reference to the executive branch, however, only two major provisions touch upon gubernatorial powers with respect to constitutional grants of authority that brings to bear upon state reorganization. Article Fourth is a tersely worded portion of the Connecticut state constitution which in section five vests supreme executive power in the governor and section twelve that states "He shall take care that the laws be faithfully executed.” (CSG Article Fourth). Endeavoring to faithfully executive the laws, governors have run headlong into a variety of institutional roadblocks. Despite the clarification of language in the 1965 constitution that granted the governor executive powers, when they have attempted to use their powers to reorganize the executive branch agencies 
entailing the consolidation or elimination of agencies, the state legislature has not always cooperated. In some cases, it has looked upon with disfavor such actions as breaching separation of powers principles by treading into a domain that they viewed as their legislative prerogative. This has been especially the case with respect to boards and commissions. State legislatures, as Conant points out, (2000) created these entities to oversee the programs and agencies they created which often lay outside the control of the governor. Independent boards and commissions have been problematic for governors throughout the United States and their reorganization or merger into cabinet departments and/or abolishment have often met with fierce resistance from clientele groups.

Accompanying the rise of a more modernized state government apparatus vis a vis constitutional reform, there also emerged what Sabato (1983) identified as a new type of governor. No longer content to be relegated to secondary status behind state legislatures, “a "new breed' of governor graced statehouses beginning in the 1980s poised to assume greater responsibility for administrative matters.”

While reducing the size and scope of government has been sought in tandem with reform efforts, it is often a secondary goal. In fact, some scholars have viewed the economy/efficiency imperative as a rhetorical device employed by governors to provide legitimacy for political interests. (Garnett 1980) In Connecticut, there have been several commissions which span the better part of the $20^{\text {th }}$ century in an attempt to capture these principles within state government. The work of these commissions and their results comprise the bulk of the following analysis.

\section{Literature Review}

Reorganization began at the federal level of government and later spread among the fifty states. The general principles were subsequently adopted by state governments in four consecutive waves. The wave metaphor was first coined by James Garnett (1980) and covers the times periods of (1914-1936), (1937-1946), (1947-1975), and the late 1970s to the present. Each of these successive time periods was inspired by federal efforts and parallels many of the same foci of concern present at the federal level. During the first half of the $20^{\text {th }}$ century, The Taft, Brownlow and Hoover Commissions were the primary catalysts for reform. The Brownlow Committee, commissioned to study the executive branch of federal government under FDR, underscored the importance of such management principles as unity of command and a limited span of control, which, while well recognized, were not being put into practice (Conant 1988, 893). Similarly, the Hoover Commission, chaired by former president Herbert Hoover, set off a wave of reform effort in the states referred to as the Little Hoover commissions (Heady 1952).

While scholars have been in disagreement as to why reorganization occurs, they have generally isolated two or three key factors that appear to be salient. In referring to this confluence of factors, Chakerian (1996) captures this sentiment well with the following observation:

Fundamental long-term trends in economic performance as well as trends in what is 
fashionable in policy affect demands for governmental actions by political interests. These pressures for action, however, must cope with an institutional environment that may facilitate or block access to the governmental decision agenda. (p. 28)

Economic factors such as fiscal crises are often the impetus for state reorganization efforts, particularly in the latter part of the $20^{\text {th }}$ century. After a long period of economic growth during the Post World War II era which continued unabated through the advent of Great Society, new state services and regulations required increased government expenditures. The size and scope of government was increasing without the accompanying managerial control mechanisms to guide much of the new activities. During economic boom periods immediately after World War II, reorganization was not viewed mainly as an attempt to reign in government spending but rather as an end in and of itself to promote better structural alignment for more efficient service delivery. As economic downturns and inflationary pressures during the 1970s' began to strain state budgets, state reorganization was viewed as a means to streamline government and achieve cost savings. In his cross-national study covering the period of 1900-1985, Conant (1992) found that state reorganization efforts were undertaken in the midst of periodic fiscal crises confronted by state governments. Similarly, Garnett (1980) and Chackerian (1996) also found empirical support for the proposition that state reorganization efforts among the states were preceded by long-wave economic decline. Compounding these economic downturns was a gradual increase in the size of government. With the advent of Great Society federal programs, the 1960s gave rise to increased state expenditures due to massive increases in state services and regulations. The size and scope of government was increasing without the accompanying managerial control mechanisms to guide much of the new activities.

While economic downturns undoubtedly lend a sense of urgency and provide a rational for governors to legitimize reorganization, alone they are not sufficient to achieve the adoption of reorganization plans. Governors may initiate reorganization efforts, however the institutional environment has been shown to be a key factor in the likelihood of adoption of reform measures by state legislatures. As a co-equal branch, party control of state legislatures is an important explanatory variable. Institutional power struggles between the executive and legislative branch often occur over reorganization due to the legislature's concern over loss of control (Chi 1992). Chakerian (1996, 36) hypothesized that reorganizations would be more likely to occur when there is high legislative party competition, when the governor's party controls the legislature and during long-wave economic downturns. However, the expected finding that the governor's party control of the legislature coupled with legislative competition would result in more frequent state reorganizations is at odds with his findings. In fact, after conducting a cross national study, he found that these conditions were actually less propitious for formal reorganization events. Formal reorganization events were fewer when the governor and the majority in the legislature shared the same party label. He posited that under conditions of party control, the governor will not have to resort to formal reorganization mechanisms to achieve his/her managerial objectives. Informal channels of control can accomplish the same objectives in a less costly and contentious manner. 
While cross-national studies in the area of state reorganization have been important in delineating general trends and patterns among the states, this study will utilize a case study approach. Connecticut shares some similarities with its sister states, it also posses certain characteristics that make it a divergent case in some important respects. By utilizing a case study method, this paper will capture some of the complexities and level of contextual detail not afforded by other cross-national comparisons.

\section{Scope of Reorganization Efforts}

Inspired by AE Buck and Luther Gulick, early state reform efforts during the first three waves were far reaching in scope (Rabin and Dodd 1985). The reorganization literature distinguishes between two major types of reorganization, comprehensive and incremental (Berkman and Reenock 2004). Comprehensive reorganization entails "the creation, abolition or the reorganization of at least four discrete agencies involving a total of four or more functional areas” (Garnet 1980, 285). Comprehensive state reorganization efforts were characterized by their ambitious plans to effect sweeping overhauls of administrative structures. These often entailed studying the machinery of state government with an eye towards streamlining and modernizing the entire administrative apparatus. Typically commissions charged with the task of reorganization often attempted to study every agency within the executive branch in order to encounter the optimal administrative structure which would foster greater managerial control. Comprehensive reorganization has a number of advantages and disadvantages. Among the advantages, comprehensive organization permits the legislature to consider the plan in its entirety. On the other hand, Young (2003) found that:

Disadvantages to comprehensive restructuring legislation are mainly that some of the portions of the proposed legislation are so controversial or otherwise unacceptable to the legislature that the whole restructuring bill atrophies or dies. (p. 16)

Furthermore, Conant $(1988,894)$ found that the primary reason for abandoning such large scale reorganization efforts was due to legislative resistance. Further fueling skepticism of comprehensive reform efforts were lingering doubts about the true cost savings associated with reorganizations which were often difficult, if not impossible, to document.

Some scholars (Chakerian 1996; Chi 1992) have taken to task the portrayal or characterization of anything less than total reorganization as failure and instead have argued for a revised understanding of what they term partial or incremental consolidation. Restructuring activities may occur in piecemeal fashion over a period of time rather than in one fell swoop. These ongoing efforts may be just as important and yield substantial outcomes even though they occur gradually. Berkman and Reenock (2004) have argued for a revised understanding of reorganization to include what they term incremental consolidation. These restructuring activities occur in piecemeal fashion over a period of time, including different time periods. As Rabin and Dodd (1985) observed, "reorganizing since 1981 has been more incremental involving only a few agencies at a time.” 
Table 1

Year Commission R

1971 Etherington

comprehensive

1976 Filer

comprehensive

1977 Gengras
Connecticut State Reorganization 1970-1977

of

Recommendations

821 Creation of the Department of

Commerce and Motor Vehicles

reduce departments

from 23-16

Departments reduced to 21

Creation of OPM

Creation of DAS

biennial budget

biennial budget

zero-based budgeting

program budgeting

strengthen governor's

role in collective

Bargaining

Changes that occur incrementally over time may be no less significant than those undertaken in a comprehensive fashion. Reorganization plans and ideas that were raised in earlier time periods and not implemented may be subsequently gain favor by later legislatures.

As Table 1 illustrates, attempts to reorganize state government in Connecticut adhere to some of the general patterns and trends detected in other states. State reorganizations during the 1970s were undertaken in the midst of economic downturns and fiscal crisis and were generally comprehensive in scope. During the 1990s, economic downturns and fiscal crisis characterized the two major attempts at reorganization. The Hull-Harper Commission (1992) did diverge from the trend away from comprehensive reorganization in its initial mandate which was limited in scope. In actuality, the commission achieved far greater success than all other previous commissions by merging and consolidating four major agencies.

\section{A Brief History of State Reorganization in Connecticut}

While the first reorganization effort began as early as 1935 under Governor Wilbur Cross, this paper will focus on more recent reorganization commissions that have occurred since 1970. An overview of these reorganization efforts demonstrates that Connecticut follows many similar patterns as its sister states in terms of the timing and scope of reform efforts as well the same pitfalls issues with respect to the adoption and implementation of plans. 


\subsection{The Etherington Commission (1970): Into the Ether}

There were two major reorganization attempts during the 1970s which Gargan (2000) dubbed "the Golden Era of State Reorganization". Fiscal crisis served as the backdrop for the Etherington Commission. As noted by the government watchdog group Connecticut Public Expenditure Council:

General fund spending had risen by $483 \%$ and the number of state employees by $69 \%$ between FY 1960 and 1972. This vast expansion of government, the commission said, would create continued pressure for higher taxes. More self-discipline within government and a reorganization of the executive branch were urgently needed to enable to the state to continue to delivery needed services while avoiding the need to raise economically burdensome new taxes. (CPEC, 7)

The Governor's Commission on Services and Expenditures (1970) otherwise known as the Etherington Commission, was illustrative of the types of reform efforts underway throughout many of the states during the 1970s. The commission, appointed by Republican Governor Meskill, was mainly comprised of business executives, was privately funded and worked without legislative authorization. The commission's work was comprehensive and resulted in 821 recommendations which covered ninety-one departments, agencies, boards and commissions. The major thrust of the proposals was to streamline and consolidate agencies in order to reduce the number from thirty three to fifteen all under the governor's control (CPEC, 8). However, many of the commission's recommendations never saw the light of day. As Morton Tenzer, a long-time scholar and observer of Connecticut state government put it:

The General Assembly, however, with Democratic majorities in both House and Senate, was skeptical of the validity of the commission appointed by Governor Meskill. Just as Republican-dominated legislatures have failed to enact the recommendations of the Democratic governors Cross and Bowles, the legislature in 1972 did not undertake enactment of the Etherington Commission Recommendations. (Tenzer, p. 158).

This finding is illustrative of the one of the key dynamics related to the relative success in terms of legislative adoption of reorganization plans. The important institutional variable referenced earlier can be seen at work in this case. It also illustrates Conant's 22 state study finding that the most successful state reorganization efforts occurred in instances of low or moderate gubernatorial/legislative conflict $(1988,895)$.

In actuality, some of the more modest recommendations made by the Etherington Commission were adopted by the state legislature. For instance, the creation of a new Department of Commerce and the reorganization of the Department of Motor Vehicles were a few of the items that survived the legislative process. Perhaps owing to the fact that Democrats held a majority during this time period, 47\% of the 151 recommendations requiring legislative action were judged not to be worthy of implementation, as opposed to just 18\% of the 684 requiring executive action.” (CPEC, p. 9) Those that were rejected by the legislature included the consolidation of the Treasurer's and Comptroller's Offices and 
Finance and Control and Tax Departments into one agency. Also jettisoned were proposals to eliminate independent governing boards for state institutions of higher education and to separate the Farmington Health Center from the University Connecticut. As Tenzer further noted, that despite the aforementioned changes, the Connecticut state government "still remained basically "unreformed" as far as the basic structure of its operations." (Tenzer, 149).

\subsection{The Filer Commission (1976): Reorganizing Without Reducing the Size of Government}

The Filer Commission on the Structure of State Government, so named after John Filer, a former Republican state senator and chairman of Aetna Life and Casualty was convened in 1976. Fiscal crisis was once again the backdrop for this commission as it had been for the previous Etherington Commission. Now that the commission operated during a Democratically-controlled legislature and under Democratic Governor Ella Grasso, it should have been a propitious circumstance to undertake reorganization. The Filer Commission recommendations fared somewhat better than its predecessor. After intense lobbying by various special interest groups, the proposal to reduce cabinet level departments from 26 to 13 resulted in only a reduction down to 21 departments. While only a partial victory, the Filer Commission did make its mark on Connecticut state government most notably for the creation of two major staff agencies, the Office of Policy and Management and the Department of Administrative Services.

A review of the legislative debates in the spring of 1977 provides a glimpse at how the recommendations of the Filer Commission fared in the General Assembly. Deliberations on Senate Bill 357 An Act concerning the Reorganization of the Executive Branch of State Government on May 23, 1977 commenced after several months of work on the bill by the Government and Administration Policy Committee. Senator Wayne Baker, the co-sponsor of the bill, introduced the day's proceedings by outlining the principles guiding the bill. A passage from Baker's speech carries several of Buck's tenets for good state government including unity of command, span of control and functional government. Baker prefaced his introductory remarks with the observation of the rapid expansion of state government and the accompanying creation of new organizational units without consideration for the existing structure. Connecticut needed to structurally align agencies to match this new growth in order to facilitate service delivery.

We have followed certain principles in the bill...There should be fewer departments reporting to the Governor. It is impossible for a governor to manage an extremely large number of independent departments and it is equally difficult for that Governor to establish priorities where every agency has as much access as the Department of Health, the Department of Consumer Protection or Economic Development. (p. 11)

To its credit, unlike the Etherington Commission, the Filer Commission did make an attempt to be more participatory by holding public hearings around the state in order to solicit input from various stakeholders in state government. In fact, in registering his opposition to the bill Senator Hudson remarked about the lobbying activity with the following: "I have been extremely displeased with the carryings on of some of the members of state government and 
lobby groups outside of state government in their attempts to impress upon us their position.” (p. 27) In an effort to be inclusive, however, they may have unwittingly provided more opportunities for opposition to express their disapproval for the plan and thereby preserve some of the agencies slated for elimination. Groups that testified during public hearings were the State Employees Association, the League of Women Voters, and major department heads of state government agencies (p.9). Twenty-eight unaffiliated agencies outside the control of the governor remained intact as the result of interest group lobbying. During legislative deliberations, some Senators expressed their opposition to the bill. The objections ranged from the view that the reorganization plan was either too bold or in some cases did not go far enough. For example, Senator Hudson did not believe that reorganization should be wielded like an ax to get rid of commissions without consideration as to how well they might be functioning (Senate proceedings, May 23, 1977. Other Senators expressed doubts that the reorganization would bring about cost savings and reduction in personnel that have been advertised by the bill's proponents. One senator asked whether the state would still have 45,000 employees and another remarked that there was no indication as to how the bill would control costs (Senate proceedings, May 23, 1977, p. 94). In a final plea for Senate Bill 357 before the final vote was taken, Senator Hudson offered the following remarks:

Political parties have alternated in power, societies change, state population has doubled in Connecticut and the economy has risen up and down. What has not changed over the years is the observation by all of the reorganization commissions that the executive branch of Connecticut government needs to be structured so that it can be more accountable to the people and their representatives. The Cross Commission stated the thesis in 1937 when it noted in its report that the principles of administrative decentralization and of checks and balances have been carried to an extreme in this organization... There is strong support for this reorganization effort by the public. (Senate Proceedings, May 23, 1977, p. 77)

Senate Bill 357 passed with 29 voting in favor and 7 opposed.

The most significant development to emerge from the Filer Commission was the creation of the Office of Policy and Management which centralized staff planning and analysis in the governor's office adding considerable policy expertise as well as a mechanism to assist the governor in formulating the budget. Underscoring the centrality of OPM's role in the executive branch, Tenzer offered the following:

After the Governor, the Secretary of OPM is the most powerful person in state government. The Secretary not only works closely with the Governor to formulate the budget, but he also becomes the chief lobbyist promoting the budget to the legislature. All other state agencies may be helped to expand their activities by favorable decisions made at OPM, or conversely, may have their programs diminished by negative judgments about their requests. (Tenzer, $p$. 157)

Since 1977, OPM has been a mainstay in the executive branch and a source of gubernatorial power and expertise. As the right arm of the chief executive, OPM prepares the governor's budget, coordinates interagency policies and intergovernmental relations. 


\subsection{The Gengras Commission Financial Management Task Force (1977)}

Once again, financial crisis was the backdrop for the Gengras Commission convened by Democratic Governor Grasso. Despite the imposition of a sales tax increase, Connecticut had a \$140,000,000 budget deficit that prompted further borrowing. It was amid these difficulties that Governor Grasso sought to improve the state's financial management by creating a commission whose charge was to identify ways to improve financial practices (CPEC, 16). Like other state governments during the 1970s, Connecticut experienced a burgeoning of programs in health, welfare, and regulation without the accompanying managerial capabilities to support these new responsibilities. Among the recommendations made by the Commission were updating accounting and control systems, better planning and budgeting, the use of long-range financial planning horizons and the provision of more timely information to make policy decisions.

The commission also included measures to assist with the implementation of the recommendations such as a two-year financial plan, program budgeting and zero based budgeting. While numerous bills were introduced during the 1978 and 1979 legislative sessions, many were not acted upon. The commission report supported the Filer proposal to create the Office of Policy and Management. It also sought to address the state's financial planning, budgeting and control processes which were found to be inadequate.

\begin{tabular}{|c|c|c|c|c|}
\hline \multirow{2}{*}{$\begin{array}{l}\text { able } 2 \\
\text { Year }\end{array}$} & & \multicolumn{3}{|c|}{ Connecticut State Reorganization 1990-2011 } \\
\hline & \multirow[t]{3}{*}{ Commission } & \multicolumn{3}{|c|}{ Recommendations } \\
\hline \multirow{12}{*}{1989} & & Type of & & Implementation by \\
\hline & & Reorg. & & Legislature \\
\hline & \multirow[t]{10}{*}{ Thomas } & \multirow[t]{10}{*}{ Comp. } & Centralization of & Commission \\
\hline & & & technology functions & was discontinued \\
\hline & & & Appointment of chief & \\
\hline & & & operating officer & \\
\hline & & & to oversee agencies & \\
\hline & & & Creation of management & \\
\hline & & & division in $\mathrm{OPM}$ & \\
\hline & & & Return to biennial & \\
\hline & & & Budgeting & \\
\hline & & & Privatization of & \\
\hline \multirow{9}{*}{1992} & \multirow{9}{*}{ Hull-Harper } & \multirow{9}{*}{ Partial } & 12 health and human & 12 health and human services \\
\hline & & & services consolidated & agencies consolidated into four \\
\hline & & & into four & \\
\hline & & & Reorganization of higher & \\
\hline & & & ed & biennial budgeting \\
\hline & & & & Creation of Office of Finance within \\
\hline & & & Consolidate the Dept. & OPM \\
\hline & & & of Developmental & \\
\hline & & & and Rehabilitative Services & \\
\hline
\end{tabular}




\subsection{The Thomas Commission to Study the Management of State Government (1989-1991)}

With the passage of more than a decade since the last state reorganization commission, the state government workforce had grown from 38,300 in 1972 to 54,184 in 1992 (U.S. Census Bureau, State Summary Table). Accompanying the growth in government employees, the number of independent boards and commissions created by the legislature mushroomed. Much like the commissions that preceded it, the impetus for the Thomas Commission was a fiscal crisis. The legislature appointed a 23 member commission to comprehensively review the entire state government. Appointed by Governor William O’Neill, DeRoy Thomas, chairman of the Hartford Insurance Group along with hired consultants studied every state agency and function from 1989-1991. The commission recommended the centralization of information technology functions, the appointment of a chief operating officer for the day to day oversight of state agencies, a return to biennial budgeting, and increased privatization of services for an overall savings of $\$ 500$ million a year (Historical Note, Connecticut State Library, 2007) which were met with skepticism and criticism on the part of the union for its exclusive focus on cutting expenditures. In a nod to long-range planning, the biennial budget passed later as Public Act 91-3 in June 1992 as part of a special legislative session. The work of the Thomas Commission was discontinued and then later restarted under the Hull-Harper Commission.

\subsection{The Hull-Harper Commission to Effect Government Reorganization (1992)}

The Harper-Hull Commission was convened to finish the work of the Thomas Commission whose work was interrupted by the election of third party Governor Lowell Weicker. Meanwhile, Connecticut was in the midst of the worst recession since the 1930s. As Robert Kravchuk (1993) recounted Connecticut was deep in the throes of a recession the levels of which had not been seen since 1930 .

At the time of Weicker's inauguration, Connecticut faced an estimated 1992 budget shortfall of some 2.4 billion. Representing approximately 38\% of projected fiscal year 1992 revenues, Connecticut's deficit would be the largest in the state's history, and the largest percentage wise in the nation (Kravchuk, 330)

In tandem with the necessary financial reforms spearheaded by Governor Weicker, including the much maligned income tax, the governor viewed the work of the commission appointed by his predecessor as necessary to bring state government under fiscal control. As Kravchuk further observed, state government was viewed as the culprit for Connecticut's worsening financial condition.

Many considered the root cause to be a state bureaucracy characterized by lethargy and inept leadership that lack the flexibility to respond to worsening economic conditions. It was in fact, contributing to Connecticut's fiscal decline. Solution of Connecticut's fiscal crisis and a comprehensive approach to administrative reform would, therefore, have to go hand in hand (1993, 331).

Characteristic of fourth wave reform efforts, the Hull-Harper Commission was less ambitious in scope. According to the Office of Legislative Review report (2002), "While the earlier 
Thomas Commission review studied the internal efficiency and operation of agencies covering almost 90\% of the state's General Fund budget and employees, the Hull-Harper mandate was to review fewer agencies and to focus on cross-organizational and coordination issues.” (Commission to Effect Government Reorganization, Final Report 1992). The commission established seven task forces to study social services, educational services, service provider network, substance abuse prevention, information technology, job creation and standardization of finance, budget and purchasing practices. The major thrust of the commission was to take a more targeted approach, and thus mainly dealt with the reorganization of Health and Human Services functions an object of considerable growth. It also proposed the merger of community and technical colleges, and introduced the application of Total Quality Management principles such as benchmarking into Connecticut state government. Many state agencies began to adopt performance measures as an overall approach known as Total Quality Management, part of the reinventing government movement forged by the federal government in the 1990s. Brudney, Hebert, and Wright (1991) observed the trend of state governments that utilized the principles of reinventing government popularized by Osborne and Gaebler (1992) and first utilized during the time of the Clinton presidency.

Yet despite its more narrowed focus, the Hull-Harper Commission managed to do what no previous commission had been able to do before which was to achieve a comprehensive reorganization of Connecticut state government as defined using Garnett's criteria. Chief among the recommendations were to consolidate the twelve health and human services agencies into four to avoid duplication and overlapping of services. This resulted in the consolidation of the three largest human services agencies into one: the Department of Income Maintenance, Human Resources and Aging. Not acted upon by the legislature was the proposal to create a consolidated Department of Developmental and Rehabilitative Services which would combine the departments of mental health and mental retardation and was vigorously opposed by interest groups (Janicki 2002). The legislature also rejected Senate Bill 367 which would have reorganized higher education into two components: the UCONN system and the State University and college system, as well as a proposal to consolidate the community, technical and two year UCONN branch campuses into five regional campuses (Janicki 2002) Among the recommendations that passed included the reintroduction of the biennial budget which had originally been proposed by the Hull-Harper Commission and the creation of an Office of Finance within the Office of Policy and Management.

Senate deliberations over Senate Bill 367 reveal some of the struggles between proponents and opponents of reform that revolve around the merger or consolidation of previously stand-alone agencies that would be subsumed under larger agencies, particularly the Department of Aging which legislators viewed as key constituency as they fought to retain it as a separate agency. Others also questioned whether the claims of greater efficiency and cost savings would materialize. In contrast to previous reorganization efforts, the Hull-Harper Commission had the distinct advantage having Senator Joe Harper serve in two capacities, one in serving as co-chair of the commission and also as a key senator during 
legislative deliberations. This was an important tactic that undoubtedly helped the bill move through the senate.

His remarks directly address the issue of cost savings that has repeatedly surfaced in legislative deliberations. Another key factor in the relative success of Hull-Harper as compared to its predecessor commissions was the active role that Governor Weicker played in expending considerable time and energy to champion reorganization. In fact, in a rare move which drew the attention of legislators was the fact that he personally testified before the committee. This signaled to legislators the degree of seriousness he accorded state reorganization. Senator Harper references both of these points with the following remarks:

The other thing that I think is important to mention is that the Hull-Harper Commission, when they made recommendations to us on human services, did so in an extraordinary manner, at least before the Human Services Committee and we were very pleased to have him there and Secretary Aronson came in to testify before the committee and at that time I asked both of those individuals whether they thought there would be a large dollar savings from the recommendations of the Hull-Harper commission on reorganization of human services. Both of these individuals said that was not the intention of the commission. It was more the intention of that committee to look at trying to provide services in a better manner to the people of Connecticut and savings of dollars, if it occurred, was secondary. (Senate proceedings, May 2, 1992, p. 97)

The Hull-Harper Commission also departed from previous commissions in the composition of the commission members. The final report (1992) touted that fact that the group was "equally representative of these two branches of government and designed to involve the various and numerous stakeholders in reorganizing state government” (p. 2).

\subsection{State Reorganization and the 2010 Gubernatorial Election}

With an unprecedented fiscal crisis in state history dwarfing all previous crises in size, scope and real dollar amounts, Connecticut state government stood at a 3.4 billion dollar deficit looming for fiscal year 2011. In a report, the National Governor's Association stated the following:

Fiscal 2010 presented the most difficult challenge for states'financial management since the Great Depression and fiscal 2011 is expected to present states with similar challenges (National Governors Association 2010, p. vii).

In this environment, state government reorganization figured prominently in the campaign rhetoric during the 2010 gubernatorial race and was put forth by both candidates as one means of tackling Connecticut's fiscal problems. With unemployment at $9.1 \%$ and a steady exodus of businesses leaving Connecticut, job growth was the top issue. Reorganization, however, was put forth by both candidates as a way to put "Connecticut's fiscal house in order” and by so doing enhance the overall economic climate. Republican gubernatorial candidate Tom Foley was poised to undertake a sweeping overhaul of state government. In fact, Foley, in an interview with the New Haven Register signaled his intentions of elected by stating that "declaring a fiscal emergency allows a governor to no longer be bound by union 
contracts”. As part of his campaign's preparation for a possible win, the Foley camp had a blueprint for a state reorganization plan that would have effectively reduced from 85 to 20 the total number of state agencies. The cornerstone of the plan was the creation of councils consisting of the leadership of existing state departments agencies under major functional groupings. The establishment of a chief operating officer would oversee the reorganization of state government (Foley campaign document, October 2010).

\section{Governor Malloy and State Reorganization: Incremental Consolidation of Higher Education}

While Malloy's proposal lacked the specificity of Foley's, his general position was to reduce to 51 from 83 the number of executive branch agencies for a total reduction of state government by $30 \%$. In the early months of his governorship, details of his plan were unveiled as part of the overall budget proposal for fiscal year 2011-12. A cornerstone of his reorganization plan is a proposal to reorganize Connecticut's system of higher education. To accomplish the overall goal of greater managerial control in higher education and to eliminate central office hierarchy in order to direct more dollars to teaching, Malloy has proposed to eliminate the various separate boards that oversee the Connecticut State University system, the community colleges and Charter Oak State College and combine them into one Board of Regents (Malloy, February 2011). Malloy stated that such changes could result in \$4.3 million dollars annually. It should be noted that the reorganization of higher education has been a perennial item on the agenda since the Filer Commission in 1976 first suggested that economies of scale could be realized through the consolidation and merger of state universities and colleges. In this respect, the eventual achievement of reorganization of higher education fits into Berkman and Reenock's (2004) model of incremental consolidation.

When the proposal was first unveiled in February, the professors' union announced its intentions to mount a strong opposition to any cost cutting measures that would stem from a higher education reorganization ( Matt Clyburn, The Recorder, Professors' Union Mobilize to Oppose Cost Cutting Measures, April 21, 2011). Despite the vociferous opposition to the plan, An Act Concerning A Reorganization of Connecticut's System of Public Higher Education was enacted by the General Assembly in May of 2011.

Perhaps sensing that some of their colleagues may not share the same appetite for reform, conservative Democratic legislators Duff, Hartley and Slossberg co-sponsored legislation to grant "all extraordinary powers" to the chief executive that may be necessary to balance the budget during fiscal crises. (Lockhart 2011). However, in response, Malloy’s administration viewed the proposal as unnecessary indicating that the current framework affords the governor adequate authority. Finally, in a special session convened for the purpose of finalizing the budget, the legislature did grant the governor the authority to make cuts subject to legislative override.

\section{General Lessons from Recent Reorganization Efforts: Routes to Reorganization}

The road to reorganization is strewn with overly ambitious plans on the part of commissions, 
a lack of buy in or cooperation from state legislatures, and lingering doubts about the measurable cost savings that reorganization plans often promise. As Young (2003) observed, the success of reorganization is dependent upon many variables the not the least of which are timing, tactics and adoption mechanisms. Based on previous reorganization efforts in Connecticut, there have been varying degrees of success. Given the great potential for failure, the question that emerges from this study is why do governors continue attempt to reorganize state government? In drawing lessons from past reorganization efforts, Young (2003) offers the following:

1) Timing - a key element to any successful reorganization effort is starting the process early in a governor's term to take advantage of the honeymoon period when legislative goodwill is at a high level. Governor Malloy signaled his intentions during the campaign and announced his plan soon after assuming office in February in conjunction in his budget address.

2) Partnership with key legislators as part of any process as well as public agencies - the least successful cases of reorganization did not involve legislators while the most successful reorganizations placed them in a central role.

3) Utilize an incremental approach to reorganization - allow for partial victories as opposed to a comprehensive approach where opposition to one section of a legislative package could undermine the whole effort.

4) Party control of both the governor and the legislature may be more beneficial to the process and increase the prospects for adoption although this is not an automatic guarantee.

5) The greater the magnitude of the fiscal crisis the greater the prospects for adoption by the legislature - the Filer and Harper-Hull Commissions were relatively successful and occurred during major fiscal crises. Governor Malloy's reorganization fits the crisis model and appears to have achieved relative success.

6) Adoption tactics - Young found that the statutory method of adoption is preferable to executive orders which legislatures view as heavy handed and as he observed the "legislature takes great umbrage to this mechanism" $(2003,116)$

7) Governor's role - a key element that emerges from this case study in terms of the likelihood of success is the role the governor plays. "A governor's determined involvement is instrumental to the success of restructuring when played out in a careful strategy of timing, tactical approaches, etc. $(2003,117)$

8) Promotional campaigns geared towards enlisting the supporting of various stakeholders - the greater the buy in by various constituencies the greater the likelihood of support for the reorganization plan.

Even when governors have not been entirely successful, reorganization efforts do serve to focus attention on problems and while they may fall short of the goal have resulted in some efficiency gains through consolidation. 


\section{Lessons Drawn from Previous Reorganization Attempts in Connecticut}

When governors in Connecticut have succeeded in bringing out administrative reform, lessons from previous efforts have been gleaned for factors that appear to have been instrumental in their accomplishment. It is evident from the most successful examples in the previous historical analysis, the Filer and Hull-Harper Commissions succeeded because governors championed the reform effort, there was strong bi-partisan support, key legislative leaders were included as commission members, and they shepherded the work through the General Assembly. All of these coincided with severe fiscal crises that lent a sense of urgency to the proceedings and legitimized administrative reform as a means to tackle budgetary problems.

\section{Conclusion}

While public policy making tends towards the status quo in general, it is more pronounced when large scale reform of government is on the agenda. Reforming state government through efforts to rearrange, consolidate, merge and possibly eliminate state agencies has met with considerable obstacles primarily the agencies themselves and their clientele groups.

Yet, despite Connecticut's penchant for steady habits, periodically policy makers have broken the log jam that has often characterized state government. Reorganizations have been successful when public officials have attempted it in a more piecemeal and incremental fashion. Time will tell whether the most recent reorganization effort will be successful. However, these legislator's words will serve as sage advice regarding state reorganization:

Efficient government depends on many variables whether good policies are chosen by the Governor and the legislature, whether competent people can be attracted to state service, whether federal policies encourage or discourage efficient state operations and whether service delivery systems are well designed to meet needs. We are not claiming that better structure is a panacea for all of the problems of state government. Good structure alone will not necessarily inspire sound decision, or recruit good people or avoid unnecessary spending or increase effective programs, but it is a good starting point for the improvement of state government. (Senator Baker, Final Senate debate, May 23, 1977)

\section{The Future of State Government Reorganization in the United States}

The Connecticut case study is illustrative of larger national trends in state reorganization both past and present. Recent developments in Connecticut state government can be viewed as a microcosm of the major efforts by governors to come to terms with a nation-wide recession that has had ripple effects on state economies across the country since 2008. In an article entitled "The Big Reset: State Governments After the Great Recession”, John Thomasian of the National Governors Association discussed the impact of the so called great recession on state government reorganization. Noting that the severity and nature of the current recession is quantitatively and qualitatively different from other recessions, he argues that states need to take a different approach to remedy the ills currently befalling state government. Instead of merely reorganizing state government, Thomasian believes that state government needs to be redesigned entirely in order to meet the needs of the $21^{\text {st }}$ century. The reset premise is 
predicated on the notion that simply reorganizing state government will not be sufficient. In order to cope with continuing shortfalls in revenue for the foreseeable future, state governments must engage in a total redesign in order to align their operations to the "new normal" state of affairs. In order to cope with this new reality, state governments must undertake a thorough reexamination of core state services. This reexamination entails deciding whether current budget priorities reflect the right mix of programs and services with the objective of determining whether there are major restructuring and cost savings available within each area (Thomasian, p. 15). This is in sharp contrast to traditional reorganization efforts in which commissions did not delve into such policy decisions and often viewed such considerations as outside of their scope.

In surveying the actions that state governments have recently taken, he noted that some likely candidates for downsizing and/or reorganization are corrections, K-12 education and public higher education. Higher education comprises roughly 11-12 percent of state expenditures, placing it in third place after K-12 education and Medicaid. In appears that Connecticut falls into line once again with national trends with the move to reorganize the system of public higher education during this past legislative session. A future research agenda is warranted to analyze the extent to which the higher education reorganization has yielded the purported benefits and cost savings proponents promised in order to gain passage in the legislature. What is certain is that Connecticut is in the midst of a significant effort to reorganize state government that will be a mainstay on the executive and legislative agenda for the foreseeable future.

\section{References}

Bell, George.1974. "State Administrative Agencies, 1972-1973, The Book of the States, 1974-1975, Lexington, KY: Council of State Government, 1974).

Berkman, Michael B. and Christopher Reenock. 2004. "Incremental Consolidation and Comprehensive Reorganization of American State Executive Branches”. American Journal of Political Science, vol. 48, No. 4, pp. 796-812.

Brudney, Jeffrey L. F. Ted Hebert and Deil S. Wright. 1991. "Reinventing Government in the States: Measuring and Explaining Administrative Reform”. Public Administration Review. January/February, vol. 59, no. 1.

Buck, A.E. 1938. The Reorganization of State Governments in the United States. New York National Municipal League.

Chackerian, Rich. 1996. “The Reorganization of State Governments 1900-1985”. Journal of Public Administration Research and Theory. Vol. 6, no. 1

Chi, Keon. S. 1992.”Trends in Executive Reorganization.” Journal of State Government 65(2):33-40.

Clyburn, Matt. Central Connecticut State University The Recorder,” Professors' Union Mobilize to Oppose Cost Cutting Measures”, April 21, 2011 Committee on the Structure of State Government, 1976, Final Report, Connecticut 
Conant, James. 1988. "In the Shadow of Wilson and Brownlow: Executive Branch Reorganization in the States, 1965 to 1987”. Public Administration Review. September/October 1988.

Connecticut General Assembly, Final Senate Debate, May 23, 1977

Connecticut General Assembly, Final Senate Debate, April 30, 1992

Connecticut Public Expenditure Council. "Remaking State Government a History of Efficiency Studies in Connecticut from Cross to Gengras with Recommendations for the Thomas Commission” Public Policy Report 3;1 January 1990.

Devine, Christopher. 2006. "Running Against the Political Winds: How Gubernatorial Campaign

Strategies Contribute to Mixed Partisan Outcomes in Mixed Partisan Outcomes in Simultaneous Gubernatorial and Presidential Elections”. Honors Paper, Connecticut College.

Gargan, John J. 2000. Handbook of State Administration. CRC Press.

Garnett, James. 1980 Reorganizing State Government: The Executive Branch. Administration and Society, vol. 12.

Governor's Commission on Services and Expenditures, 1971. Connecticut State Government.

Gulick, Luther and Lyndall Urwick. 1937. Papers on the Science of Administration. New York Institute of Public Administration

Heady, Ferrel. 1952. “States Try Reorganization”. National Municipal Review. Vol. 1, issue 7, pages 334-345

Hull-Harper Commission to Effect Government Reorganzation. Final Report. March 1992

Janicki, Mary M. “Office of Policy and Management and other State’s Budget Agencies”. OLR Research Report, November 25, 2002. Connecticut General Assembly.

Kravchuk, Robert S. 1993. The "New Connecticut": Lowell Weicker and the Process of Administrative Reform. Public Administration Review. July/August 1993, vol. 53, no. 4.

Lockhart, Brian. January 29, 2011. "Some legislators want governor to have more budget authority”.

National Governors Association and the National Association of State Budget Officers. “Fiscal Survey of States”. Fall 2010, Washington, D.C.

Rabin, Jack and Don Dodd. 1985. State and Local Government Administration. Marcel Dekker

Sabato, Larry. 1983. Goodbye to good-time Charlie The American Governorship Transformed. CQ Press. Washington, DC. 


\section{Macrothink

Thomasian, John. 2010.”The Big Reset: State Government After the Great Recession”. National Governors Association Center for Best Practices. February 23, 2010.

Tenzer, Morton. 1987. State Administration. Professor Emeritus. UCONN School of Public Policy. Unpublished Manuscript.

Wilson, Woodrow. 1887. “The Study of Administration”. Political Science Quarterly, vol. 2 (June 1887)

Young, Richard D. 2003. "State Restructuring Implementation Issues and Strategies. USC Institute for Public Policy and Research. 